\title{
The ubiquitous mussel: Bathymodiolus aff. brevior symbiosis at the Central Indian Ridge hydrothermal vents
}

\author{
Z. P. McKiness ${ }^{1,2}$, C. M. Cavanaugh ${ }^{1, *}$ \\ ${ }^{1}$ Department of Organismic and Evolutionary Biology, Harvard University, 16 Divinity Avenue, Cambridge, \\ Massachusetts 02138, USA
}

${ }^{2}$ Present address: National Animal Disease Center, United States Department of Agriculture, Agricultural Research Service, 2300 Dayton Avenue, Ames, Iowa 50010, USA

\begin{abstract}
The discovery and exploration of hydrothermal vents on the Central Indian Ridge (CIR) yielded invaluable samples for further resolution of the biogeography of chemoautotrophic symbioses. Mytilid mussels were collected from 2 CIR hydrothermal vent fields and preliminary molecular analyses suggested phylogenetic affinity with the western Pacific vent mussel Bathymodiolus brevior. Resolving whether this mussel, designated B. aff. brevior, hosts a dual symbiosis, as characterized for the 2 Mid-Atlantic Ridge hydrothermal vent mussel species, or a single chemoautotrophic symbiosis, as seen in the Pacific vent mussel species, will provide insight into the evolutionary history of mytilid symbioses. Ultrastructural, physiological, and molecular evidence are reported herein which support the presence of a single endosymbiont phylotype with chemoautotrophic metabolism. Phylogenetic analyses placed this symbiont in the same clade as the vesicomyid clam symbionts, prompting discussion regarding the evolutionary origin of chemoautotrophic symbioses in vent bivalves.
\end{abstract}

KEY WORDS: Chemoautotrophic endosymbiosis · Central Indian Ridge · Hydrothermal vent . Bathymodiolus spp.

Resale or republication not permitted without written consent of the publisher

\section{INTRODUCTION}

Research at deep-sea hydrothermal vents (discovered only 25 yr ago) has resulted in a radically altered perception of life in the aphotic zone of the world's oceans. Unrivaled biomass, coupled with extreme geological and chemical stochasticity, has redefined ideas regarding not only deep-sea biology, but the nature and function of ecosystems. Completely removed from sunlight, primary productivity at hydrothermal vents is driven by chemical energy. Life in these novel habitats is characterized by an astounding array of physiological, morphological and behavioral adaptations. The hallmark of hydrothermal vent biology is the recurring theme of chemoautotrophic bacterial symbioses, which have been described for the majority of the dominant vent macrofauna (Fisher 1990, Cavanaugh 1994, Nel- son \& Fisher 1995). The bacterial symbionts harness energy from reduced inorganic sulfur compounds to drive carbon fixation and, ultimately, either directly or indirectly provide their host with organic carbon. The host organism is able to use a combination of traits to sequester and transport necessary substrates to the aerobic chemoautotrophic bacteria.

As hydrothermal vent exploration has progressed, and additional locales have been identified and sampled, many key evolutionary questions regarding the widespread nature of chemoautotrophic symbioses have arisen. In particular, biogeographic 'provinces' are under continuous evaluation as more sites are explored (e.g. Tunnicliffe et al. 1998). The recent discoveries of the Kairei and Edmond hydrothermal vent fields on the Central Indian Ridge (CIR) were of profound importance in the context of further resolving 
biogeographic patterns in the world's hydrothermal vent ecosystems (Hashimoto et al. 2001, Van Dover et al. 2002). The biology of CIR vents was a great mystery, given the disparate communities inhabiting the Atlantic and Pacific vents. Forming a key physical link between the Mid-Atlantic Ridge (MAR) hydrothermal vents and the western Pacific back arc basins, the CIR hydrothermal vents were found to be characterized by a blend of Atlantic and Pacific faunas (Van Dover et al. 2001). Massive swarms of shrimp dominated the vent fields, visually reminiscent of MAR vents. However, much like western Pacific vent sites, sea anemones, interspersed with clumps of mussels and snails, dominated the benthic environment.

The CIR mussels, designated Bathymodiolus aff. brevior, are more closely related to the western Pacific mussel $B$. brevior than to the MAR mussels $B$. azoricus and $B$. puteoserpentis, as revealed by molecular studies based on NADH dehydrogenase subunit 4 (ND4) (Van Dover et al. 2001, Won et al. 2002). Yamanaka et al. (2003) reported transmission electron microscope (TEM) and sulfur-isotope data that indicate the presence of bacterial symbionts in this species. This mussel has also been described as $B$. marisindicus based on morphological data (Hashimoto 2001); however, because morphological characters may reflect phenotypic plasticity, a new species designation may not be warranted. Pending additional data indicating that the CIR mussel is a separate species from $B$. brevior, this mussel will be referred to as $B$. aff. brevior herein, since the molecular results indicate high genetic identity with $B$. brevior.

While the CIR vents lack the well-studied vesicomyid clam and vestimentiferan tubeworm symbioses, the presence of mytilid mussels at this locale is significant given their ubiquity in the Atlantic and Pacific Oceans. Among symbiont-hosting vent fauna, only mussels have been described from all known hydrothermal vent biogeographic provinces (Table 1): Juan de Fuca (unnamed new species), East Pacific Rise, EPR, (Bathymodiolus thermophilus), MAR (B. azoricus and $B$. puteoserpentis), western Pacific (B. brevior and B. elongatus), and Okinawa Trough (B. japonicus, B. platifrons, and B. septemdierum). Thus, finding mytilid mussels at the CIR vents, although not unexpected, further establishes their global distribution. In addition to their ubiquity, Bathymodiolus spp. mussels are unique in the range of symbiont composition observed in the gills of different species (Table 1). To date, mussels are known from hydrothermal vents and cold seeps that host either sulfur-oxidizing chemoautotrophic symbionts (Cavanaugh 1983, Nelson et al. 1995, Dubilier et al. 1998) or methane-oxidizing (methanotrophic) symbionts (Childress et al. 1986). Furthermore, mussels that host 'dual symbioses' involving both types of bacteria are known from the Gulf of Mexico cold seeps (Cavanaugh et al. 1987, Cavanaugh 1993, Fisher et al.

Table 1. Bathymodiolus spp. Symbiont composition and geographic distribution of mussels from deep-sea hydrothermal vents. Presence of symbiont type demonstrated by ultrastructural, physiological/immunological, isotopic, and/or molecular evidence.

C: chemoautotrophic symbionts; M: methanotrophic symbionts; ?: symbiont type has not been investigated

\begin{tabular}{|c|c|c|c|c|}
\hline Species & $\begin{array}{l}\text { Symbiont } \\
\text { type }\end{array}$ & Location & $\begin{array}{l}\text { Depth } \\
(\mathrm{m})\end{array}$ & Source \\
\hline \multicolumn{5}{|l|}{ Indian Ocean } \\
\hline Bathymodiolus aff. brevio & ior $\mathrm{C}$ & Central Indian Ridge & $2450-3300$ & This study \\
\hline \multicolumn{5}{|l|}{ Pacific Ocean } \\
\hline B. brevior & $\mathrm{C}$ & $\begin{array}{l}\text { North Fiji Basin } \\
\text { Lau Basin }\end{array}$ & $\begin{array}{l}2200 \\
1850\end{array}$ & $\begin{array}{l}\text { Von Cosel \& Metivier (1994), } \\
\text { Dubilier et al. (1998) }\end{array}$ \\
\hline B. elongatus & $?$ & North Fiji Basin & 2200 & Von Cosel \& Metivier (1994) \\
\hline B. japonicus & $?, \mathrm{M}$ & Okinawa Trough & 1200 & Hashimoto \& Okutani (1994), Fujiwara et al. (2000) \\
\hline B. platifrons & M & Okinawa Trough & 1200 & $\begin{array}{l}\text { Hashimoto \& Okutani (1994), Fujiwara et al. (2000), } \\
\text { Barry et al. (2002) }\end{array}$ \\
\hline B. septemdierum & $\mathrm{C}, ?$ & Okinawa Trough & 1200 & Hashimoto \& Okutani (1994), Fujiwara et al. (2000) \\
\hline B. thermophilus & $\mathrm{C}$ & $\begin{array}{l}\text { East Pacific Rise } \\
\text { Galapagos Rift }\end{array}$ & $\begin{array}{l}2000-2600 \\
2500\end{array}$ & $\begin{array}{l}\text { Cavanaugh (1983), Kenk \& Wilson (1985), } \\
\text { Nelson et al. (1995) }\end{array}$ \\
\hline Bathymodiolus n. sp. ${ }^{\mathrm{a}}$ & $\mathrm{C}$ & Juan de Fuca & 2500 & McKiness et al. (2005) \\
\hline \multicolumn{5}{|l|}{ Atlantic Ocean } \\
\hline B. azoricus & $\mathrm{C}, \mathrm{M}$ & Mid Atlantic Ridge & $800-2300$ & $\begin{array}{l}\text { Trask \& Van Dover (1999), Von Cosel et al. (1999), } \\
\text { Fiala-Médioni et al. (2002) }\end{array}$ \\
\hline B. puteoserpentis & $\mathrm{C}, \mathrm{M}$ & Mid Atlantic Ridge & $2200-3600$ & $\begin{array}{l}\text { Cavanaugh et al. (1992), Distel et al. (1995), } \\
\text { Robinson et al. (1998) }\end{array}$ \\
\hline
\end{tabular}


1993) and the MAR hydrothermal vents (Cavanaugh et al. 1987,1992, Cavanaugh 1993, Fisher et al. 1993, Distel et al. 1995, Robinson et al. 1998, Fiala-Médioni et al. 2002). Remarkably, the dual symbioses in these mytilids represent the only known example of the stable coexistence of 2 physiologically and phylogenetically distinct bacteria within the same eukaryotic host cell. Thus, the discovery of a new species of mussel provides potential evolutionary clues to the evolution of the neighboring MAR dual symbiosis species.

Here, the presence and nature of symbionts in the CIR mussel, Bathymodiolus aff. brevior, are evaluated using ultrastructural, enzymatic and molecular methods. The phylogenetic affinities of the putative symbiont are assessed using comparative sequence analyses including other known bivalve symbionts. We present evidence supporting the presence of a single, chemoautotrophic symbiont population in $B$. aff. brevior. Furthermore, the 16S rRNA phylotype of the $B$. aff. brevior symbiont is more closely related to the vesicomyid clam symbionts than the mytilid mussel chemoautotrophic symbionts.

\section{MATERIALS AND METHODS}

Organisms. Bathymodiolus aff. brevior specimens were collected in April 2001 by the remotely operated vehicle, ROV 'Jason' at the Kairei $\left(25^{\circ} 19^{\prime} \mathrm{S}, 70^{\circ} 02^{\prime} \mathrm{E}\right.$;

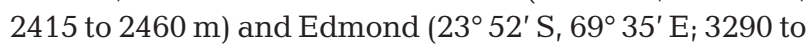
$3320 \mathrm{~m}$ ) vent fields on the CIR. The mussels were transported to the surface in insulated containers within $24 \mathrm{~h}$ of collection, and immediately transferred to chilled seawater $\left(4^{\circ} \mathrm{C}\right)$. Specimens were dissected and tissues were preserved for microscopy or frozen in liquid nitrogen for enzymatic and molecular studies. The latter samples were stored at $-70^{\circ} \mathrm{C}$ on board ship, then transported to the laboratory on dry ice and stored at $-80^{\circ} \mathrm{C}$.

Microscopy. Pieces of Bathymodiolus aff. brevior tissue were dissected from the middle portion of the gill on board the ship (RV 'Knorr') and preserved in $3 \%$ glutaraldehyde in $0.1 \mathrm{M}$ sodium cacodylate, $0.4 \mathrm{M}$ sodium chloride buffer, $\mathrm{pH}$ 7.4. Upon return to the laboratory, gill filaments were dehydrated through a graded ethanol series, post-fixed in osmium tetroxide, stained en bloc with uranyl acetate, and embedded in Spurr's resin. Thick sections of gill filaments were examined from 2 individuals from Kairei and 1 from Edmond. Thin sections stained with lead citrate and uranyl acetate were examined for 1 Kairei mussel with a Zeiss 10CA transmission electron microscope.

Enzyme assays. Cell free extracts of Bathymodiolus aff. brevior gill tissue $(\mathrm{n}=3)$ were analyzed for activities of enzymes diagnostic of carbon fixation (ribulose 1,5bisphosphate carboxylase/oxygenase, RubisCO) and methylotrophy (methanol dehydrogenase). RubisCO activity was assayed using the ${ }^{14} \mathrm{C}$ incorporation method as described in Robinson et al. (1998), with fresh spinach used as the positive control. Methanol dehydrogenase activity was tested using the spectrophotometric method of Anthony \& Zatman (1964). Gill tissue of the MAR mussel B. azoricus, which is known to host methanotrophic symbionts (Fiala-Médioni et al. 2002), was used as the positive control. For both assays, boiled cell free extracts and samples lacking substrate, ribulose 1,5-bisphosphate and methanol, respectively, were used as negative controls.

PCR, cloning, and sequencing of $16 \mathrm{~S}$ rRNA. DNA was extracted from mussel gill tissue $(n=4)$ using the DNeasy tissue kit (Qiagen). The universal bacteria primers $27 \mathrm{f}$ and 1492r (Weisburg et al. 1991) were used to amplify 16S rRNA from gill DNA for Bathymodiolus aff. brevior from both Kairei $(n=2)$ and Edmond $(n=2)$ fields. Reactions included primers ( $1 \mu \mathrm{M}$ each), $0.25 \mathrm{mM}$ deoxynucleoside triphosphates, $2.5 \mathrm{mM} \mathrm{MgCl}_{2}, 1 \mathrm{U}$ Taq polymerase, $1 \times$ PCR buffer and 0.01 to $1 \mathrm{ng}$ DNA. PCR was performed using an initial 2 min denaturation at $94^{\circ} \mathrm{C}$, followed by 35 cycles at $94^{\circ} \mathrm{C}$ for $1 \mathrm{~min}, 50^{\circ} \mathrm{C}$ for $1 \mathrm{~min}$, and $74^{\circ} \mathrm{C}$ for $2 \mathrm{~min}$, and concluding with $74^{\circ} \mathrm{C}$ for $10 \mathrm{~min}$. PCR products were cloned using the TOPO TA cloning kit (Invitrogen). DNA was extracted from positive clones using the QIAprep Spin Miniprep kit (Qiagen) and screened using RsaI digests to discriminate between inserts. Partial ( 700 bp) single strand sequences were obtained for all positive candidates. For a subset of these positive clones, the entire 16S rRNA insert was sequenced in both directions and was re-sequenced in cases of ambiguity. All sequencing reactions were carried out on an ABI 3100 sequencer (Applied Biosystems) and reactions used either M13 vector primers or universal bacteria 16S rRNA primers (27f, 530f, 1492r; Weisburg et al. 1991).

Confirmation of symbiont 16S rRNA sequence. RTPCR was used to confirm that the bacterial 16S rRNA sequence obtained was not a contaminant and, in fact, was from the symbiont of Bathymodiolus aff. brevior. Since the presence of RNA is indicative of active cells, a sequence generated from RNA, via cDNA, supports the presence of a viable population of that phylotype in the RNA source. Total RNA, extracted from the symbiontcontaining gill tissue of 1 mussel from each CIR vent field using the RNeasy Mini Kit (Qiagen), was reverse transcribed using the Thermoscript ${ }^{\mathrm{TM}}$ RT-PCR System (Invitrogen). The $16 \mathrm{~S}$ rRNA gene was then amplified as described above, using the $27 \mathrm{f}$ and $1492 \mathrm{r}$ universal primers, and directly sequenced, using the following internal primers: 530f (universal), 42f GATTGAACGCTGGCGG, 515r CCGCGGCTGCTGGCAC, 1473r TTACCCCAG TCATGAATCACACC (all numbering based on Escherichia coli). 
Phylogenetic analyses. Sequence analyses were performed using the Genetics Computer Group (GCG) software package (Wisconsin Package) and PAUP 4.0 b10 (Swofford 2002). In GCG, sequences were aligned by Pileup and then manually edited based on the $16 \mathrm{~S}$ rRNA secondary structure of Escherichia coli (Boros et al. 1979). Phylogenetic analyses were conducted using PAUP 4.0 b10. Maximum parsimony trees were generated with heuristic searches using random-sequence addition with 100 replicates and TBR branch-swapping methods. The same search conditions were used for a 500 replicate bootstrap analysis. Analyses were based on approximately $1.5 \mathrm{~kb}$ section of 16S rRNA; gaps were treated as missing data. The organisms included in the phylogenetic analyses are listed in Table 2. The 16S rRNA sequence of the Bathymodiolus aff. brevior symbiont has been deposited in GenBank under Accession No. DQ077891.

\section{RESULTS}

\section{Microscopy}

Transmission electron micrographs revealed Gram negative bacteria enclosed in vacuoles within Bathymodiolus aff. brevior gill epithelial cells (Fig. 1). The symbiont-containing bacteriocytes occurred between symbiont-free intercalary cells. Symbionts appeared in rod and coccoid shapes and lacked the intracytoplasmic membranes typical of methanotrophic bacteria. Multiple symbionts occurred within a single vacuole and each bacteriocyte included multiple vacuoles. These vacuoles tend to be positioned at the apical end of host cells, which bear microvilli and are exposed to seawater.
Table 2. Bacteria 16S rRNA gene sequences included in this study (all species fall within Gamma Proteobacteria)

\begin{tabular}{|c|c|c|}
\hline Host group & Species & $\begin{array}{l}\text { GenBank } \\
\text { Accession No. }\end{array}$ \\
\hline \multicolumn{3}{|c|}{ Chemoautotrophic symbionts } \\
\hline \multicolumn{3}{|l|}{ Bivalvia } \\
\hline Mytilidae & $\begin{array}{l}\text { Bathymodiolus aff. brevior symbiont } \\
\text { Bathymodiolus puteoserpentis symbiont } 1 \\
\text { Bathymodiolus thermophilus symbiont } \\
\text { Solemya velum symbiont }\end{array}$ & $\begin{array}{l}\text { DQ077891 } \\
\text { U29163 } \\
\text { M99445 } \\
\text { M90415 }\end{array}$ \\
\hline Lucinidae & Lucinoma aequizonata symbiont & M99448 \\
\hline Vesicomyidae & $\begin{array}{l}\text { Calyptogena elongata symbiont } \\
\text { Calyptogena magnifica symbiont } \\
\text { Calyptogena pacifica symbiont } \\
\text { Vesicomya gigas symbiont }\end{array}$ & $\begin{array}{l}\text { AF035719 } \\
\text { AF035721 } \\
\text { AF035723 } \\
\text { AF035726 }\end{array}$ \\
\hline Vestimentifera & Riftia pachyptila symbiont & M99451 \\
\hline \multicolumn{3}{|c|}{ Methanotrophic symbionts } \\
\hline \multicolumn{3}{|l|}{ Bivalvia } \\
\hline Mytilidae & $\begin{array}{l}\text { Bathymodiolus childressi symbiont } \\
\text { Bathymodiolus puteoserpentis symbiont } 2\end{array}$ & $\begin{array}{l}\text { U05595 } \\
\text { U29164 }\end{array}$ \\
\hline \multicolumn{3}{|c|}{ Free-living bacteria } \\
\hline & $\begin{array}{l}\text { Escherichia coli } \\
\text { Thiomicrospira crunogena } \\
\text { Thiomicrospira thyasirae }\end{array}$ & $\begin{array}{l}\text { AF233451 } \\
\text { L40810 } \\
\text { AF016046 }\end{array}$ \\
\hline
\end{tabular}

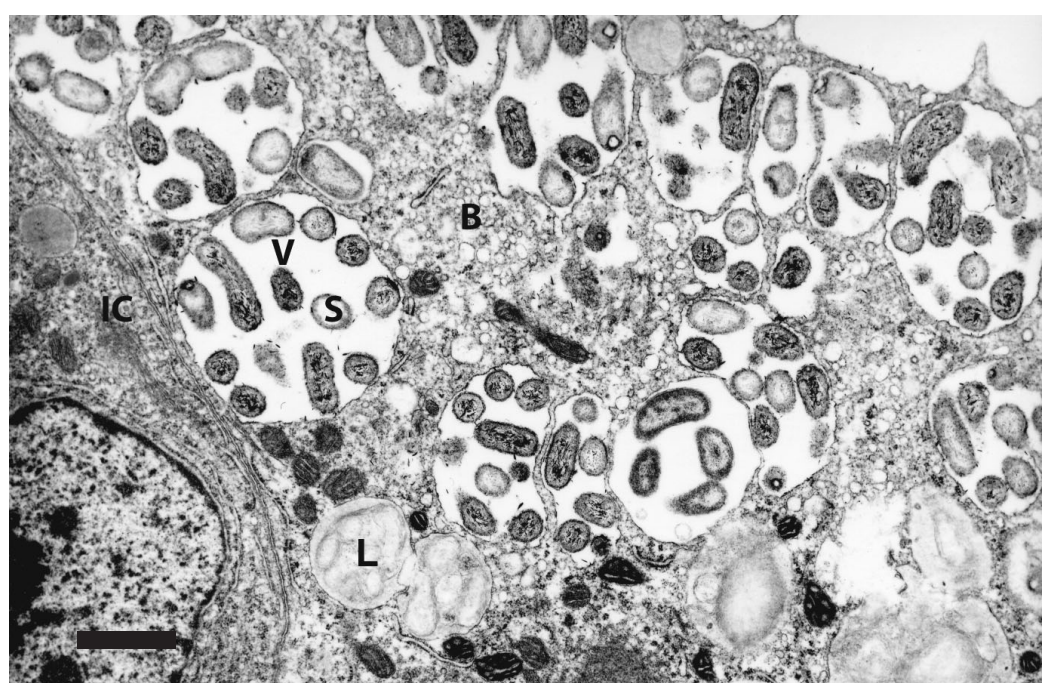

Fig. 1. Bathymodiolus aff. brevior. Transmission electron micrograph of transverse section through gill filament showing bacterial symbionts, showing bacteriocyte (B) next to symbiont-free intercalary cell (IC). Symbionts (S) are located within vacuoles (V) in bacteriocyte. Putative lysosomal bodies (L) are located in distal portion of bacteriocyte. Scale bar $=5 \mu \mathrm{m}$

\section{Enzyme assays}

RubisCO activity was detected in cell free extracts of Bathymodiolus aff. brevior gill tissue from 3 speci-

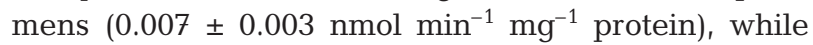

methanol dehydrogenase activity was not detected. For both assays, activity was detected in the respective positive controls, spinach and $B$. azoricus, and was not detected in boiled cell free extracts and substrate-free reactions. 


\section{Sequence analyses}

PCR from the 4 samples using the $27 \mathrm{f}$ and $1492 \mathrm{r}$ Bacteria primers yielded a band that was the expected $1.5 \mathrm{~kb}$ in length. Each PCR was then cloned and 10 positive clones from each mussel were assessed. Restriction endonuclease analyses showed a dominant band pattern for 36 of 40 positive clones. The 36 positive clones were then screened using single-strand sequencing, and 30 of those clones yielded the same $16 \mathrm{~S}$ rRNA sequence $(<0.1 \%$ variation). For 2 mussels from the Kairei site, 2 clones each were fully sequenced in both directions, resulting in nearly identical 1473 bp 16S rRNA sequences; there were 2 bp substitutions in 1 clone as compared to the other 3 , which were identical.

Subsequent sequence confirmation of the symbiont phylotype in host tissue was accomplished via RT-PCR

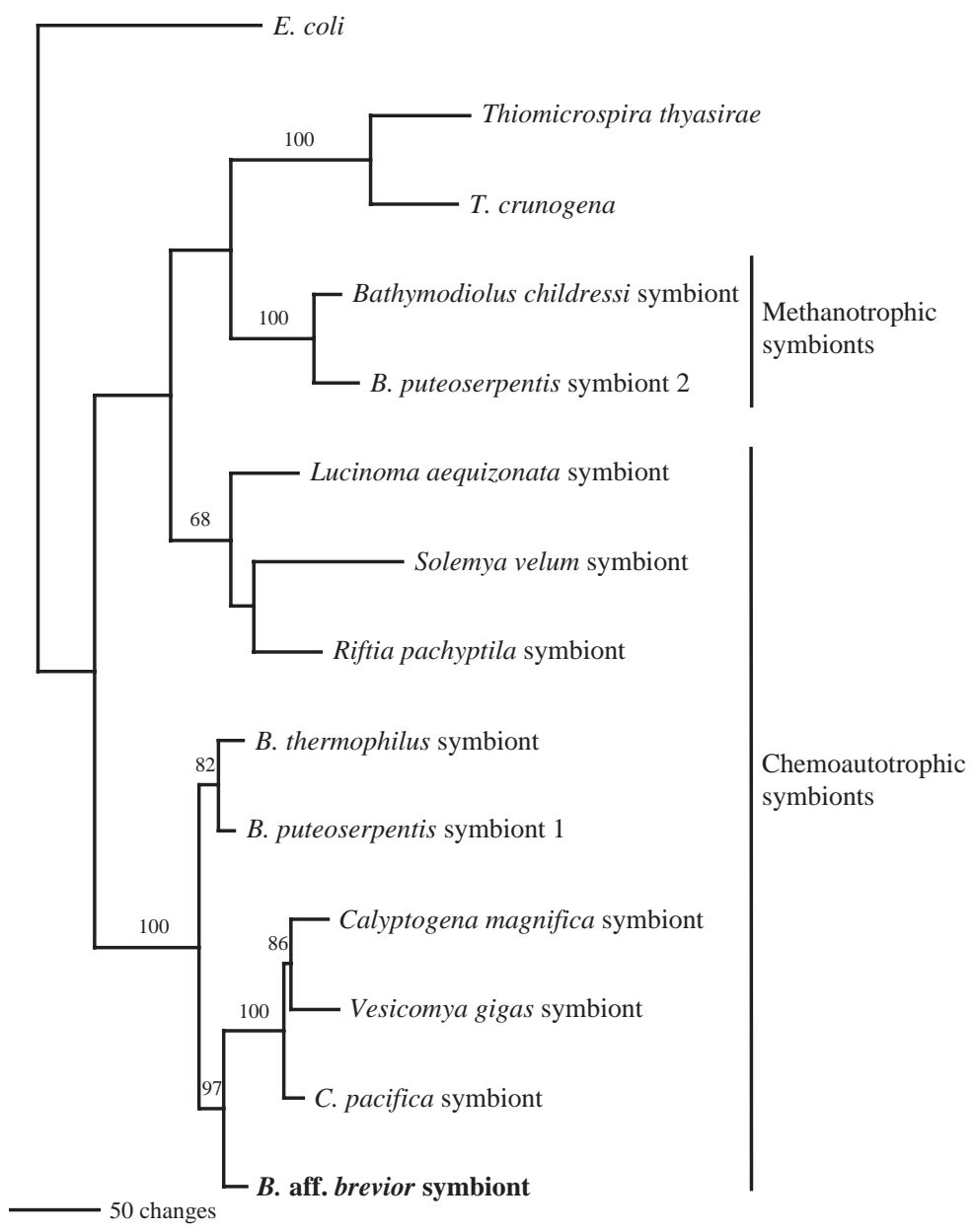

Fig. 2. Bathymodiolus aff. brevior. Phylogenetic relationship of mussel symbionts inferred from 16S rRNA gene sequences. Tree is strict consensus of 7 parsimony trees (tree length 1004), based on $1458 \mathrm{bp}$ of $16 \mathrm{~S}$ rRNA. Bootstrap values exceeding $50 \%$ from 1000 replicate bootstrap are indicated above branches. Scale bar $=$ number of changes and cDNA direct sequencing of 1 mussel from Kairei and 1 mussel from Edmond. The fully sequenced 16S rRNA RT-PCR products for both mussels were $100 \%$ identical to the three indistinguishable fully sequenced clones. This 'consensus' sequence was designated as the Bathymodiolus aff. brevior symbiont phylotype.

Phylogenetic analyses yielded 7 most parsimonious trees that all placed the symbiont of Bathymodiolus aff. brevior with the mytilid mussel and vesicomyid clam chemoautotrophic symbionts (Fig. 2). This clade, containing both mytilid mussel and vesicomyid clam symbionts, had $100 \%$ bootstrap support. The mytilid mussel methanotrophic symbionts fell in a separate clade, with $100 \%$ bootstrap support (as shown previously: Distel \& Cavanaugh 1994); this was distinct from the clade containing the chemoautotrophic mussel symbionts, which included the $B$. aff. brevior symbiont. Interestingly, the $B$. aff. brevior symbiont groups with the vesicomyid clam symbionts (supported by a $97 \%$ bootstrap value) rather than clustering with the mytilid mussel chemoautotrophic symbiont group ( $82 \%$ bootstrap support). Additional phylogenetic analyses were conducted using different proportions of vesicomyid clam and mytilid mussel symbionts to evaluate the stability of this topology with respect to taxon sampling. All resulting phylogenies showed that the $B$. aff. brevior symbiont clustered with the vesicomyid clam symbionts, sister to the other mytilid mussel chemoautotrophic symbionts (results not shown).

\section{DISCUSSION}

Ultrastructural, physiological and molecular evidence all support the existence of a single population of chemoautotrophic symbiont in the mussel Bathymodiolus aff. brevior from the recently discovered CIR hydrothermal vents. Indeed, the western Pacific mussel $B$. brevior, which is most closely related to the CIR mussel, has been characterized as having only chemoautotrophic symbionts (Dubilier et al. 1998). In addition, a recent study of this mussel, referred to as $B$. marisindicus, reported TEM and stable sulfur isotope data that also are consistent with the presence of chemoautotrophic symbionts (Yamanaka et al. 2003).

In TEMs, a single endosymbiont morphotype was observed in Bathymodiolus aff. brevior gill epithelial cells; while both rod and coccoid shapes were observed, this may be an 
artifact of symbiont orientation within the vacuole. This finding is in agreement with previously published TEMs for these mussels (Yamanaka et al. 2003). In addition, as seen in the chemoautotrophic endosymbionts observed in B. brevior (Dubilier et al. 1998) and B. thermophilus (Le Pennec 1984, Fiala-Médioni et al. 1986), these bacteria lack the intracytoplasmic membranes typical of methanotrophic bacteria.

The RubisCO activity, albeit low in these mussels, is comparable to previously reported values for vent mytilids hosting chemoautotrophic symbionts (Fisher et al. 1993, Nelson et al. 1995, Fiala-Médioni et al. 2002). RubisCO activity is notoriously difficult to measure in mytilid gill tissues, given their high levels of proteolytic activity (Nelson et al. 1995). In fact, for Bathymodiolus puteoserpentis (the MAR mussel which hosts both types of symbiont), RubisCO activity was undetectable (Cavanaugh et al. 1992), although immunological blots later confirmed its presence (Robinson et al. 1998). Consistent with the lack of observable methanotrophic endosymbionts in the TEMs and the single 16S rRNA sequence detected, methanol dehydrogenase activity was absent. Furthermore, this finding of a single population of chemoautotrophic symbionts is consistent with the previously published stable carbon isotope value for $B$. aff. brevior mantle tissue of $-29.9 \pm 0.9 \%$ (Van Dover 2002).

Also in line with a single symbiont population, only one 16S rRNA phylotype was amplified and sequenced from mussels collected from both CIR vent fields. Sequence confirmation via RT-PCR indicated that this phylotype is the endosymbiont of Bathymodiolus aff. brevior. This additional step is critical in establishing the origin of the sequence in host tissue and ruling out the possibility that it is a contaminant.

The lack of variation in the $16 \mathrm{~S}$ rRNA gene sequences obtained from multiple clones isolated from multiple individuals, is notable, though the implications in the context of symbiont transmission are unclear. Cary et al. (1993) reported preliminary work indicating maternal transmission in the chemoautotrophic symbiont of the EPR mussel Bathymodiolus thermophilus. Conversely, recent evidence based on host and symbiont sequence variation in a hybrid zone, suggests environmental transmission of the chemoautotrophic symbiont of the MAR mussel $B$. azoricus, which is known to host a dual symbiosis (Won et al. 2003). Won et al.'s (2003) report also featured ultrastructural evidence for environmental uptake of symbionts. However, these data may have been confounded by methodological artifacts, and maternal transmission cannot be eliminated as a possibility. A phylogenetic approach was recently used to address cospeciation (and indirectly symbiont transmission) in the bathymodioline mussel symbioses. Analyses of host and symbiont phylogenetic congruence provided weak support for cospeciation of chemoautotrophic symbionts, but no evidence for cospeciation between the mussels and their methanotrophic symbionts, although small samples sizes may have biased these results (McKiness 2004). Future work aimed at evaluating mussel larvae and gametes for the presence of symbionts is necessary in order to establish the mode of symbiont transmission in these mussels. In addition, studies of genetic variation in both symbiont and host populations, as well as investigations of phylogenetic congruence of larger samples of host and symbiont, will allow a more robust assessment of cospeciation in bathymodioline mussel symbioses.

From an evolutionary perspective, the position of the Bathymodiolus aff. brevior symbiont within the vesicomyid clade is striking. This topology may reflect a shared evolutionary history for the mytilid mussel and vesicomyid clam symbioses. In a thoughtful discussion on the evolution of the mussel and vesicomyid clam symbioses, Distel (1998) notes that, based on the fossil record, vesicomyids evolved much more recently (95 to 135 million yr ago) than the mytilid mussels' symbioses (150 million yr ago). This timing is coincident with the divergence of the mussel and vesicomyid clam symbionts, presumed to have occurred 125 to 300 million yr ago, based on a molecular clock estimate for $16 \mathrm{~S}$ rRNA (Distel 1998). Thus, the question as to the nature of the origin of chemoautotrophic symbioses characteristic of mytilid mussels and vesicomyid clams arises. Was the initial symbiosis in both mytilid mussels and vesicomyid clams with the same symbiont, which subsequently cospeciated with the respective host groups?

While the Bathymodiolus aff. brevior symbiont provides a potential link between these 2 host groups, there is a significant difference between the symbionts of the mussels and vesicomyid clams. Sequence data for the RubisCO gene, coupled with Western blots, show that the EPR vent mussel $B$. thermophilus has symbionts expressing a Form I RubisCO while the vent vesicomyid clam Calyptogena magnifica hosts symbionts with a Form II RubisCO (Cavanaugh \& Robinson 1996). The Form I and Form II RubisCO enzymes are biochemically, physiologically and evolutionarily distinct (Cavanaugh \& Robinson 1996, Tabita 1999), and the fact that bacteria which are closely related on the basis of 16S rRNA and which also inhabit similar environments express different forms of this enzyme is puzzling. While the Form I RubisCO is known to exhibit high $\mathrm{CO}_{2}$ affinity, the Form II enzyme shows low $\mathrm{CO}_{2}$ affinity, consistent with growth in high- $\mathrm{CO}_{2}$ conditions (Jordan \& Ogren 1981, Tabita 1988). Interestingly, there are examples of free-living bacteria that express both forms of RubisCO, such as the vent isolate Thiomicrospira L-12 (C. Cavanaugh unpubl. data) and 
Hydrogenovibrio marinus (Yaguchi et al. 1994). Thus, there is the potential for an ancestral symbiont with both Form I and Form II RubisCOs which gave rise to the mussel and clam symbionts with subsequent differential retention of the enzyme. Moreover, the endosymbionts probably experience very disparate conditions in the gills of their respective hosts, as mussels and vesicomyid clams have not only different $\mathrm{CO}_{2}$ concentrations, but also different $\mathrm{O}_{2}$ concentrations, given abundant hemoglobin present in vesicomyid clam blood (Arp et al. 1984). In addition, there are substantial differences in gill morphology and ciliation between filibranch mussels and eulamellibranch clams (Atkins 1937).

Evaluation of the Bathymodiolus aff. brevior symbiosis within the context of the chemical environment of the habitat is consistent with chemoautotrophic, as opposed to methanotrophic, symbionts. Preliminary analyses revealed high levels of sulfide dissolved in hydrothermal fluid sampled from both CIR vent fields (Van Dover et al. 2001). End member fluid methane concentrations reported for both Kairei and Edmond ( 0.2 and $0.4 \mathrm{mmol} \mathrm{kg}^{-1}$, respectively) are very low compared to other hydrothermal vents (Van Dover et al. 2001), perhaps selecting against the presence of methanotrophic symbioses. Alternatively, methanotrophic symbionts may be present but escaped detection because of low abundance.

The prospect of a dual symbiosis is particularly compelling in the context of establishing the evolutionary origin of this phenomenon within the mytilid mussels. Future work characterizing the ancestral state of symbiosis in these hosts will be necessary in order to evaluate whether there was a single origin for dual symbioses. Coupled with forthcoming results of a host phylogeny, these data will provide critical insight into the evaluation of the evolution of mytilid dual symbioses.

This opportunity to study this mytilid-chemoautotroph symbiosis was exciting given the key biogeographic location of the host Bathymodiolus aff. brevior as the previously unexplored CIR. These vents provide a physical link between the Atlantic and Pacific Oceans, evoking questions regarding the origin of the taxa at the Kairei and Edmond vent fields. Interestingly, this mussel appears to share evolutionary alliances with the western Pacific mussel $B$. brevior and not the mussels of the MAR, which hosts dual symbioses. Furthermore, its symbiont shows phylogenetic affinities to the vesicomyid clam symbionts, evoking questions regarding the origin of chemoautotrophic symbioses in the vesicomyid clams and mytilid mussels. By increasing the taxonomic sampling, patterns in the evolution of these symbionts can be more accurately assessed. Evaluation of the degree of genetic heterogeneity within the Kairei and Edmond vent mussels will provide a context within which to address the apparent lack of variation within and between the symbiont populations as well as, ultimately, the role of cospeciation in the evolution of this interaction. This finding opens the door for further questions regarding the evolutionary origin of symbioses in deep-sea mussels, as well as the nature of symbiont transmission and the role of cospeciation in the development of this interaction.

Acknowledgements. We thank the captain and crew of the $\mathrm{RV}$ 'Knorr', the pilots and crews of the ROV 'Jason', and the chief scientist C. L. Van Dover and the scientific party of Leg 162-13 for their support and assistance. In addition, we thank K. Scott for assistance with RubisCO assays and L. Kerr for assistance with TEM. This research was supported by NSF OCE-9712358 and NSF OCE-0002460 (C.M.C) and the NIH Genetics Training Grant (Z.P.M.).

\section{LITERATURE CITED}

Anthony C, Zatman LJ (1964) The microbial oxidation of methanol 2. The methanol-oxidizing enzyme of Pseudomonas sp. M27. Biochem J 92:614-621

Arp AJ, Childress JJ, Fisher CRJ (1984) Metabolic and blood gas transport characteristics of the hydrothermal vent bivalve Calyptogena magnifica. Physiol Zool 57:648-662

Atkins DA (1937) On the ciliary mechanisms and interrelationships of lamellibranchs. Part III: Types of lamellibranch gills and their food currents. Q J Microsc Sci 79: 375-421

Barry JP, Buck KR, Kochevar RK, Nelson DC, Fujiwara Y, Goffredi SK, Hashimoto J (2002) Methane-based symbiosis in a mussel, Bathymodiolus platifrons, from cold seeps in Sagami Bay, Japan. Invertebr Biol 121:47-54

Boros I, Kiss A, Venetianer P (1979) Physical map of the seven ribosomal RNA genes of Escherichia coli. Nucleic Acids Res 6:1817-1830

Cary SC, Warren W, Anderson E, Giovannoni SJ (1993) Identification and localization of bacterial endosymbionts in hydrothermal vent taxa with symbiont-specific polymerase chain reaction amplification and in situ hybridization techniques. Mol Mar Biol Biotechnol 2:51-62

Cavanaugh CM (1983) Symbiotic chemoautotrophic bacteria in marine invertebrates from sulphide-rich habitats. Nature 302:58-61

Cavanaugh CM (1993) Methanotroph-invertebrate symbioses in the marine environment: ultrastructural, biochemical, and molecular studies. In: Kelly DP (ed) Microbial growth on C1 compounds. Intercept, Andover, p 315-328

Cavanaugh CM (1994) Microbial symbiosis: patterns of diversity in the marine environment. Am Zool 34:79-89

Cavanaugh CM, Robinson JJ (1996) $\mathrm{CO}_{2}$ fixation in chemoautotroph-invertebrate symbioses: Expression of Form I and Form II RubisCO. In: Lidstrom ME, Tabita FR (eds) Microbial growth on $\mathrm{C}^{1}$ compounds. Kluwer, Dordrecht, p 285-292

Cavanaugh CM, Levering PR, Maki JS, Mitchell R, Lidstrom ME (1987) Symbiosis of methylotrophic bacteria and deep-sea mussels. Nature 325:346-348

Cavanaugh CM, Wirsen C, Jannasch HJ (1992) Evidence for methylotrophic symbionts in a hydrothermal vent mussel (Bivalvia: Mytilidae) from the Mid-Atlantic Ridge. Appl Environ Microbiol 58:3799-3803 
Childress JJ, Fisher CR, Brooks JM, Kennicutt MC II, Bidigare $\mathrm{R}$, Anderson AE (1986) A methanotrophic marine molluscan (Bivalvia, Mytilidae) symbiosis: mussels fueled by gas. Science 233:1306-1308

Distel D (1998) Evolution of chemoautotrophic endosymbioses in bivalves. BioScience 48:277-286

Distel DL, Cavanaugh CM (1994) Independent phylogenetic origin of methanotrophic and chemoautotrophic bacterial endosymbioses in marine bivalves. J Bacteriol 176: 1932-1938

Distel DL, Lee HKW, Cavanaugh CM (1995) Intracellular coexistence of methano- and thioautotrophic bacteria in a hydrothermal vent mussel. Proc Natl Acad Sci USA 92: 9598-9602

Dubilier N, Windoffer R, Giere O (1998) Ultrastructure and stable carbon isotope composition of the hydrothermal vent mussels Bathymodiolus brevior and B. sp. affinis brevior from the North Fiji Basin, western Pacific. Mar Ecol Prog Ser 165:187-193

Fiala-Médioni A, Métivier C, Herry A, Le Pennec M (1986) Ultrastructure of the gill of the hydrothermal vent mytilid Bathymodiolus sp. Mar Biol 92:65-72

Fiala-Médioni A, McKiness Z, Dando P, Boulegue J, Mariotti A, Alayse-Danet A, Robinson J, Cavanaugh C (2002) Ultrastructural, biochemical, and immunological characterization of two populations of a new species of mytilid mussel, Bathymodiolus azoricus, from the Mid-Atlantic Ridge: evidence for a dual symbiosis. Mar Biol 141:1035-1043

Fisher CR (1990) Chemoautotrophic and methanotrophic symbioses in marine invertebrates. Rev Aquat Sci 2:399-436

Fisher CR, Brooks JM, Vodenichar JS, Zande JM, Childress JJ, Burke RA Jr (1993) The co-occurrence of methanotrophic and chemoautotrophic sulfur-oxidizing bacterial symbionts in a deep-sea mussel. PSZN I: Mar Ecol 14: $277-289$

Fujiwara Y, Takai K, Uematsu K, Tsuchida S, Hunt J, Hashimoto J (2000) Phylogenetic characterization of endosymbionts in three hydrothermal vent mussels: influence on host distributions. Mar Ecol Prog Ser 208:147-155

Hashimoto J (2001) A new species of Bathymodiolus (Bivalvia: Mytilidae) from hydrothermal vent communities in the Indian Ocean. Venus 3:141-149

Hashimoto J, Okutani T (1994) Four new mytilid mussels associated with deepsea chemosynthetic communities around Japan. Venus 53:61-83

Hashimoto J, Ohta S, Gamo T, Chiba H and 6 others (2001) First hydrothermal vent communities from the Indian Ocean discovered. Zool Sci 18:717-721

Jordan DB, Ogren WL (1981) Species variation in the specificity of ribulose bisphosphate carboxylase/oxygenase. Nature 291:513-515

Kenk VC, Wilson BR (1985) A new mussel (Bivalvia, Mytilidae) from hydrothermal vents in the Galapagos Rift zone. Malacologia 26:253-271

Le Pennec M (1984) Anatomie, structure et ultrastructure de la branchie d'un Mytilidae des sites hydrothermaux du Pacifique oriental. Oceanol Acta 7:517-523

McKiness ZP (2004) Evolution of endosymbioses in deep-sea bathymodioline mussels (Mollusca:Bivalvia). PhD thesis, Harvard University, Cambridge, MA

McKiness ZP, McMullin ER, Fisher CR, Cavanaugh CM (2005) A new bathymodioline mussel symbiosis at the Juan de Fuca hydrothermal vents. Mar Biol (in press)

Nelson D, Fisher C (1995) Chemoautotrophic and methanotrophic endosymbiotic bacteria at deep-sea vents and seeps. In: Karl D (ed) Microbiology of deep-sea hydrothermal vents. CRC Press, Boca Raton, FL, p 125-167

Nelson DC, Hagan KD, Edwards DB (1995) The gill symbiont of the hydrothermal vent mussel Bathymodiolus thermophilus is a psychrophilic, chemoautotrophic, sulfur bacterium. Mar Biol 121:487-495

Robinson JJ, Polz MF, Fiala-Médioni A, Cavanaugh CM (1998) Physiological and immunological evidence for two distinct C1-utilizing pathways in Bathymodiolus puteoserpentis, a dual endosymbiotic mussel from the Mid-Atlantic Ridge. Mar Biol 132:625-633

Swofford DL (2002) PAUP*. Phylogenetic analysis using parsimony ( ${ }^{*}$ and other methods). Sinauer Associates, Sunderland, MA

Tabita FR (1988) Molecular and cellular regulation of autotrophic carbon dioxide fixation in microorganisms. Microbiol Rev 52:155-189

Tabita FR (1999) Microbial ribulose 1,5-bisphosphate carboxylase/oxygenase: A different perspective. Photosynth Res 60:1-28

Trask JL, Van Dover CL (1999) Site-specific and ontogenetic variations in nutrition of mussels (Bathymodiolus sp.) from the Lucky Strike hydrothermal vent field, Mid-Atlantic Ridge. Limnol Oceanogr 44:334-343

Tunnicliffe V, MacArthur AG, McHugh D (1998) A biogeographical perspective of the deep-sea hydrothermal vent fauna. Adv Mar Biol 34:353-442

Van Dover C (2002) Trophic relationships among invertebrates at the Kairei hydrothermal vent field (Central Indian Ridge). Mar Biol 141:761-772

Van Dover CL, Humphris SE, Fornari D, Cavanaugh CM and 22 others (2001) Biogeography and ecological setting of Indian Ocean hydrothermal vents. Science 294:818-822

Van Dover C, German CR, Speer KG, Parson LM, Vrijenhoek RC (2002) Evolution and biogeography of deep-sea vent and seep invertebrates. Science 295:1253-1257

Von Cosel R, Metivier B (1994) Three new species of Bathymodiolus (Bivalvia: Mytilidae) from hydrothermal vents in the Lau and North Fiji Basin, Western Pacific, and the Snake Pit area, Mid-Atlantic Ridge. Veliger 37:374-392

Von Cosel R, Comtet T, Krylova E (1999) Bathymodiolus (Bivalvia: Mytilidae) from the hydrothermal vents on the Azores Triple Junction and the Logatchev hydrothermal field, Mid-Atlantic Ridge. Veliger 42:218-248

Weisburg WG, Barns SM, Pelletier DA, Lane DJ (1991) 16S ribosomal DNA amplification for phylogenetic study. J Bacteriol 173:697-703

Won YJ, Maas PAY, Van Dover CL, Vrijenhoek RC (2002) Habitat reversal in vent and seep mussels: seep species, Bathymodiolus heckerae, derived from vent ancestors. Cah Biol Mar 43:387-390

Won YJ, Hallam SJ, O'Mullan GD, Pan IL, Buck KR, Vrijenhoek RC (2003) Environmental acquisition of thiotrophic endosymbionts by deep-sea mussels of the genus Bathymodiolus. Appl Environm Microbiol 69:6785-6792

Yaguchi T, Chung SY, Igarashi Y, Kodama T (1994) Cloning and sequence of the L2 form of RubisCO from a marine obligately autotrophic hydrogen-oxidizing bacterium, Hydrogenovibrio marinus Strain MH-110. Biosci Biotechnol Biochem 58:1733-1737

Yamanaka T, Mizota C, Fujiwara Y, Chiba H, Hashimoto J, Gamo T, Okudaira T (2003) Sulphur-isotopic composition of the deep-sea mussel Bathymodiolus marisindicus from currently active hydrothermal vents in the Indian Ocean. J Mar Biol Assoc UK 83:841-848 